$6-2011$

\title{
Modulation of Fibroblast Inflammatory Response by Surface Modification of a Perfluorinated Ionomer
}

Thelma Iris Valdes

University of Connecticut School of Medicine and Dentistry

Follow this and additional works at: https://opencommons.uconn.edu/uchcres_articles Part of the Medicine and Health Sciences Commons

\section{Recommended Citation}

Valdes, Thelma Iris, "Modulation of Fibroblast Inflammatory Response by Surface Modification of a Perfluorinated Ionomer" (2011). UCHC Articles - Research. 151.

https://opencommons.uconn.edu/uchcres_articles/151 


\title{
Modulation of fibroblast inflammatory response by surface modification of a perfluorinated ionomer
}

\author{
Thelma I. Valdes, \\ Center for Biomaterials, University of Connecticut Health Center, Farmington, Connecticut \\ 06030-1715
}

Winston Ciridon, Department of Bioengineering, University of Washington, Box 355061, Seattle, Washington 98195-5061

Buddy D. Ratner, and Department of Bioengineering, University of Washington, Box 355061, Seattle, Washington 98195-5061

James D. Bryers ${ }^{a}$

Department of Bioengineering, University of Washington, Box 355061, Seattle, Washington 98195-5061

\section{Abstract}

\begin{abstract}
An ideal surface for implantable glucose sensors would be able to evade the events leading to chronic inflammation and fibrosis, thereby extending its utility in an in vivo environment. Nafion ${ }^{\mathrm{TM}}$, a perfluorinated ionomer, is the membrane material preferred for in situ glucose sensors. Unfortunately, the surface properties of Nafion ${ }^{\mathrm{TM}}$ promote random protein adsorption and eventual foreign body encapsulation, thus leading to loss of glucose signal over time. Details of the techniques to render Nafion ${ }^{\mathrm{TM}}$ nonprotein fouling are given in a previous article [T. I. Valdes et al., Biomaterials 29, 1356 (2008)]. Once random protein adsorption is prevented, a biologically active peptide can be covalently bonded to the treated Nafion ${ }^{\mathrm{TM}}$ to induce cellular adhesion. Cellular responses to these novel decorated Nafion ${ }^{\mathrm{TM}}$ surfaces are detailed here, including cell viability, cell spreading, and type I collagen synthesis. Normal human dermal fibroblasts (NHDFs) were cultured on control and modified Nafion ${ }^{\mathrm{TM}}$ surfaces. Findings indicate that $\mathrm{Nafion}^{\mathrm{TM}}$ modified with 10\% 2-hydroxyethyl methacrylate and $90 \%$ tetraglyme created a nonfouling surface that was subsequently decorated with the YRGDS peptide. NHDFs were shown to have exhibited decreased type I collagen production in comparison to NHDF cells on unmodified $\mathrm{Nafion}^{\mathrm{TM}}$ surfaces. Here, the authors report evidence that proves that optimizing conditions to prevent protein adsorption and enhance cellular adhesion may eliminate fibrous encapsulation of an implant.
\end{abstract}

\section{INTRODUCTION}

One of the main obstacles for the long-term implantation of some medical devices is the creation of a fibrotic capsule around the implant-tissue interface of the device. This dense, collagenous capsule is not detrimental to some devices, but drastically limits the function of implantable biosensors, which are dependent on the influx of analytes to or from the surface. Increasing the lifetime of an implantable glucose biosensor, for example, would be quite 
advantageous for diabetic patients, decreasing their chances of related complications, such as blindness, kidney failure, heart disease, among others. ${ }^{1,2}$

In the development of a fully implantable glucose sensor, several different types of membrane materials have been utilized, including polytetrafluoroethylene, ${ }^{3-10}$ polyvinylchloride ${ }^{11-17}$ cellulose or cellulose acetate, ${ }^{15,17-29}$ and polyurethane. ${ }^{8,28,30-41}$ Included in this list is the use of the perfluorinated ionomer, Nafion ${ }^{\mathrm{TM}}$ (Dupont, Inc.). Nafion ${ }^{\mathrm{TM}}$ is a perfluorinated ionomer, and as such, is highly ion conductive and can function as a cation exchange polymer. In addition, like Teflon, Nafion ${ }^{\mathrm{TM}}$ is extremely resistant to chemical attack. For a glucose sensor, Nafion ${ }^{\mathrm{TM}}$ serves four purposes, namely, (a) to reject negative molecules; (b) to physically protect the glucose oxidase enzyme that drives the chemical reaction of the biosensor (acting as a physical barrier); (c) to act as a glucose transport-limiting membrane, thereby reducing the oxygen requirement of the biosensor; and (d) to maintain some level of biocompatibility, especially after curing the Nafion ${ }^{\mathrm{TM}}$ membrane. ${ }^{42,43}$ As has been stated in literature, when comparing materials for the construction of glucose biosensors, Nafion ${ }^{\mathrm{TM}}$ based glucose sensor provides the best long term response stability. ${ }^{17}$ There are numerous publications that utilize Nafion ${ }^{\mathrm{TM}}$ in the design of a glucose biosensor and the most recent publications are listed. ${ }^{44-93}$

Like other coatings, however, Nafion ${ }^{\mathrm{TM}}$ is subject to the changes that occur in the subcutaneous tissues once an implant is in place. The cascade of events leading to fibrosis has been described previously. ${ }^{94}$ Briefly, after protein adhesion and the start of the acute inflammatory stage, chronic inflammation begins typically approximately 3-5 days after implantation. For a subcutaneous device, such as a biosensor, skin fibroblasts begin to secrete chronic inflammatory cytokines, the most abundant having been found to be TGF $\beta-1 .{ }^{95}$ Once exposed to TGF $\beta$, myofibroblasts will differentiate from quiescent fibroblasts, and the production of type I collagen begins. Type I collagen is the most prominent component of fibrotic tissue and has been shown to be a main component of what is known as the "foreign body reaction."

Various surface modification strategies have been utilized in an attempt to modulate the inflammatory response. One attempt has been to eliminate surface "fouling" or the random and unlimited adsorption of proteins to a surface. To this end, one of the most prominent techniques has been the use of polyethylene glycol (PEG) coated surfaces as detailed in Refs. 96-100 to name a few. Although PEG is effective in preventing nonspecific protein adsorption, its nonfouling character is dependent on the surface chain density and can be subject to damaged by oxidants. ${ }^{101}$ The use of plasma deposition of ethylene glycol dimethyl ether or "oligoglymes" has been shown as an alternative to materials that utilize PEG in their design. ${ }^{102,103}$ Although these strategies have been shown to be effective in vitro, studies have shown that after 4 weeks of implantation, fibrous capsules around coated and uncoated implants were virtually the same. ${ }^{104,105}$

Research in the area of biologically active surfaces has included much work with the ubiquitous peptide sequence, arginine-glycine-aspartic acid or RGD, as it is known for its properties for cell adhesion. The RGD site has been identified in many extracellular matrix proteins, including vitronectin, fibrinogen, collagen, laminin, osteopontin, and tanascin, and is known to bind to approximately half of all identified integrins. ${ }^{106}$ Little research has been done in the use of a plasma method to functionalize surfaces. In particular, little research has been conducted to modulate the fibroblast response.

In a previous publication, we detailed the surface modification of the perfluorinated ionomer, Nafion ${ }^{\mathrm{TM}}$. Briefly, by using a radio frequency glow discharge deposition (RFGDD) method, surfaces were modified by using a combination of two monomers, thereby creating 
a new surface able to prevent random protein adsorption and concomitantly be reactive enough to display a biologically active peptide. ${ }^{44}$ This goal was accomplished by mixing (1) tetraethylene glycol dimethyl ether (tetraglyme) and (2) 2-hydroxyethyl methacrylate (HEMA) at different ratios. The first monomer provided a nonfouling base, and the second monomer provided the reactive hydroxyl groups that were necessary for the subsequent chemical attachment of the YRGDS peptide, a known cell adhesion ligand. In this article, we detail the cellular response to these surfaces; metrics used included cell viability, spreading, engagement of integrin receptors, and type I collagen synthesis.

\section{MATERIALS AND METHODS}

\section{A. Preparation of surface coatings and surface analysis}

Details of the synthesis of surfaces can be found in Ref. 44. Plasma polymerization, or polymerization initiated by a partially ionized gas generated by the RFGDD method, is widely used for preparing coatings and insulating layers. ${ }^{107}$

Several variations of surface coatings were created using two base monomers individually or by combining the two at different concentrations. They were (1) tetraethylene glycol dimethyl ether (tetraglyme, Aldrich Catalog No. 172405), known for its nonfouling characteristics, ${ }^{102}$ and (2) HEMA (PolySciences Inc., ophthalmic grade), ${ }^{108}$ known for its biocompatibility and available reactive hydroxyl groups. Combinations used were as follows: pure tetraglyme, 2.5\% HEMA with $97.5 \%$ tetraglyme; 5\% HEMA with $95 \%$ tetraglyme, $10 \%$ HEMA with 90\% tetraglyme; and pure HEMA. Once prepared, surfaces were evaluated for the degree to which they were able to repel serum proteins, such as albumin and fibronectin. Surfaces were then characterized for their hydroxyl group content and were assessed for their ability to covalently bind a biological peptide, YRGDS. Method details are outlined elsewhere. ${ }^{44}$ Briefly, the peptide was radiolabeled using the Iodobead ${ }^{\mathrm{TM}}$ method and was covalently bound to available surface hydroxyl groups using $1,1^{\prime}$ carbonyldiimidazole (CDI)(Sigma) in anhydrous acetone. Once bound, YRGDS bound peptide was quantified via a gamma counter and YRGDS peptide linked to modified Nafion ${ }^{\mathrm{TM}}$ surfaces was calculated $\left(\mathrm{ng} / \mathrm{cm}^{2}\right) .{ }^{44}$ It was observed that the 10\% HEMA, 90\% tetraglyme modified surfaces provided the lowest protein adsorption with a sufficient amount of available hydroxyl groups. In addition, 10\% HEMA surfaces were found to exhibit the most cell spreading (see details below). Therefore, all cellular experiments reported here were carried out on either 10\% HEMA-90\% tetraglyme surfaces or unmodified Nafion ${ }^{\mathrm{TM}}$ and compared to various control surfaces (tissue culture surfaces).

\section{B. Adhesion assays to Nafion ${ }^{\mathrm{TM}}$ and modified Nafion ${ }^{\mathrm{TM}}$ materials}

NHDFs (Cambrex Inc., Catalog No. 2511) were grown on T75 flasks (Corning). Low glucose Dulbecco's modified Eagle's medium was made from powder (Sigma Catalog No. D-2902 (no phenol red) or D-5523 (with phenol red dye)] and supplemented with 1\%/ streptomycin and $3.7 \mathrm{~g} / \mathrm{l}$ of sodium bicarbonate. The $p \mathrm{H}$ of the medium was 7.2 and was maintained constant with (4-(2-hydroxyethyl)-1-piperazineethanesulfonic acid buffer (Invitrogen Inc.), which was added to the medium at a final concentration of $20 \mathrm{mM}$. The medium was sterilized by filtration ( $0.2 \mu \mathrm{m}$ filter, Stericups, Millipore) and then supplemented with $10 \%$ fetal bovine serum (FBS), as needed to grow the cells. Following sterilization under an UV light for 10 min, custom chambers containing Nafion ${ }^{\mathrm{TM}}$, tetraglyme-coated Nafion ${ }^{\mathrm{TM}}$, or tetraglyme-HEMA coated Nafion ${ }^{\mathrm{TM}}$ were exposed to either (1) a protein solution containing bovine serum albumin $(100 \mu \mathrm{g} / \mathrm{ml})$, (2) a protein solution containing fibronectin $(100 \mu \mathrm{g} / \mathrm{ml})$, (3) a $10 \%$ serum solution in low glucose media, or (4) were covalently decorated with the YRGDS peptide, as discussed in Ref. 44. 
After $24 \mathrm{~h}$, surfaces were rinsed three times with sterile phosphate buffered saline (PBS) $(p \mathrm{H}=7.2)$ and NHDF cells were concentration of $10000 \mathrm{cells} / \mathrm{cm}^{2}$ in the custom chambers for a period of either 4 or $24 \mathrm{~h}$ (for unmodified Nafion ${ }^{\mathrm{TM}}$ as well as TCPS) and for $24 \mathrm{~h}$ for modified surfaces (tetraglyme and YRDGS-decorated surfaces). Cell concentrations were quantified on various surfaces via the use of an epifluorescence microscope (Zeiss, Inc.)(10x objective). To clearly visualize NHDF cells, the dual Live/Dead ${ }^{\mathrm{TM}}$ stain system (L3224 Molecular Probes, Inc.), consisting of SYTO 10 (green fluorescent nucleic acid "Live" stain) and ethidium homodimer-2 (red fluorescent nucleic acid "dead" stain), was used. Direct visualization of Live/Dead ${ }^{\mathrm{TM}}$ stained cells allowed a direct cell count enumeration and an estimate of the area of cell spreading. Photographs were taken of at least 3 spots on one well (4 wells/membrane, on two membranes per surface type) using a charge coupled device camera and MAGNAFIRE image capture software. Adhesion of cells was then analyzed for statistical differences between groups [using a two-factor a one-way analysis of variance (ANOVA)] in the unmodified surfaces and between groups in the modified surfaces. In addition, a single unmodified group (10\% serum group) and a single modified group (10\% HEMA) were compared to check for statistical differences between the number of cells adhered.

\section{Immunocytochemistry for actin and paxillin}

The ability of cells to sense and respond appropriately to changes in their immediate external environment is dictated by the engagement of cell integrin receptors to an adhesion ligand. Changes in the Nafion ${ }^{\mathrm{TM}}$ substrate may lead to changes in cell signaling mechanisms that can be examined by immunocytochemical techniques. Two relevant intracellular proteins were chosen: actin microfilaments and paxillin. Actin, a $43 \mathrm{kD}$ protein, is the most abundant protein in typical eukaryotic cells, accounting for approximately $15 \%$ of total protein. Actin filaments are typically associated with the formation of the cytoskeleton. Paxillin, a $68 \mathrm{kD}$ protein, is an "adaptor" protein that facilitates optimal signal transduction through its ability to recruit multiple intermediates of specific signaling pathways to specific regions within the cell. ${ }^{109}$ Once these are recruited, proper signaling mechanisms can alter complex events within cells, such as changes in gene expression and reorganization of the cytoskeleton.

Three types of surfaces were examined, namely, a control surface-tissue culture chamber slide (TCCS)(Nunc, Inc.), an unmodified Nafion ${ }^{\mathrm{TM}}$ surface, and a 10\% HEMA modified Nafion $^{\mathrm{TM}}$ surface. Unmodified Nafion ${ }^{\mathrm{TM}}$ and TCCS received an overnight $10 \%$ serum treatment at $37{ }^{\circ} \mathrm{C}$. Surfaces coated with $10 \%$ HEMA were further modified with YRGDS peptide, as outlined in Ref. 44. After rinsing surfaces with sterile PBS, a cell suspension was used to submerge the Nafion ${ }^{\mathrm{TM}}$ membranes; cell suspensions were designed to produce a plated concentration of $10000 \mathrm{cells} / \mathrm{cm}^{2}$. Cells were left in contact with the surface samples for $24 \mathrm{~h}$ in a $\mathrm{CO}_{2}$ incubator at $37{ }^{\circ} \mathrm{C}$ in serum-free media. Cells were then fixed with a $2 \%$ paraformaldehyde solution, rinsed with PBS, blocked with a 10\% FBS solution (in PBS), and incubated with a primary antibody prepared in 5\% FBS in PBS for $1 \mathrm{~h}$ at room temperature. Primary antibodies were anti- $\boldsymbol{a}$-actin (Sigma, Catalog No. A2066) and anti- $a$ paxillin (BD Pharmingen Catalog No. 610051). Surfaces were then rinsed with PBS three times and incubated with a 5\% FBS solution containing two different secondary antibodies. To visualize paxillin, a fluorescently labeled goat antimouse secondary antibody was chosen (Molecular Probes, AlexaFlour 594, A-11005). To stain for actin, a fluorescently labeled goat antirabbit secondary antibody was chosen (Molecular Probes, AlexaFlour 488, A11008). Images were collected using an epifluorescence Zeiss microscope (40x objective lens) and MAGNAFIRE image capture software. For actin, a fluorescein isothiocyanate filter $(A b s=495 \mathrm{~nm} ; E m=520 \mathrm{~nm})$ was used. For paxillin, a Texas red filter was used 
(Abs=583 nm; Em=603). Single-color images were collected separately and then merged into one image using the MAGNAFIRE software.

\section{Proliferation assays}

Proliferation of NHDFs was carried out on three different surfaces: unmodified Nafion ${ }^{\mathrm{TM}}$ (with and without preadsorbed protein), 10\% HEMA modified Nafion ${ }^{\mathrm{TM}}$, and a control surface, TCPS. Proliferation of NHDF on these surfaces was assessed via Cell Titer 96® Aqueous One Solution Cell Proliferation Assay (Promega, Inc.) or via direct visualization of unmodified Nafion ${ }^{\mathrm{TM}}$ surfaces using the Live/Dead stain and IMAGEJ as outlined above. The Cell Titer 96 assay is a colorimetric method, containing a tetrazolium compound [3(4,5-dimethylthiazol-2-yl)-5-(3-carboxymethoxyphenyl)-2-(4-sulfophenyl)-2H-tetrazolium, inner salt; MTS (a)] and an electron coupling reagent [phenazine ethosulfate (PES)]. As described by the manufacturer, the MTS tetrazolium compound (Owen's reagent) is bioreduced by cells into a colored formazan product that is soluble in tissue culture medium. The PES was believed to interfere with unmodified Nafion ${ }^{\mathrm{TM}}$ surfaces since absorbance levels remained constant, despite a large number of cells on the surface (as verified by Live/ Dead stain).

Nafion ${ }^{\mathrm{TM}}$ surfaces were prepared as outlined above (unmodified with $10 \%$ serum or no other protein, or YRGDS-modified 10\% HEMA surfaces). Control TCPS received no prior protein treatment. Fibroblast cells were plated at 20000 cells $/$ well $\left(10000 \mathrm{cells} / \mathrm{cm}^{2}\right.$ in 500 $\mu \mathrm{l}$ ) in phenol red-free media (containing $10 \%$ serum). Phenol red-free media were chosen to avoid any potential interference with the colorimetric change in the Cell Titer assay. $4 \mathrm{~h}$ after plating (day 0), two wells per surface type received $100 \mu \mathrm{l}$ of Cell Titer assay and were returned to $37^{\circ} \mathrm{C}$ for $1 \mathrm{~h}$. Contents of each well's cell suspension were transferred to standard 24-well plates and read using a fluorescent plate reader at $490 \mathrm{~nm}$ wavelength. Exactly $24 \mathrm{~h}$ later, the medium in each remaining well was replaced with fresh, serum-free medium and Cell Titer 96 was added. This step ensured that evaporation of the medium was minimized and that assays were performed on a full $500 \mu \mathrm{l}$ to correspond to the standard calibration. This process was repeated again until day 4. Cell Titer 96 assay absorbance values were correlated with cell numbers using a standard curve, made with serum-free media, using the same type of TCPS plate (Falcon, BD). A similar procedure was carried out with unmodified Nafion ${ }^{\mathrm{TM}}$ surfaces, except that cells were counted using the Live/Dead stain.

\section{E. Quantification of type I collagen}

Quantification of type I collagen was carried out because it is known to be the main component of a fibrotic capsule that eventually surrounds an implant. Collagen synthesis has been found to increase in renal fibroblasts in the presence of IL-1 (Ref. 110) and ascorbic acid. ${ }^{111,112}$ Thus, in order to discern if differences in surface chemistry would modulate the synthesis of collagen, cells on unmodified and 10\% HEMA modified Nafion ${ }^{\mathrm{TM}}$ were supplemented with IL-1, ascorbic acid, glucose oxidase, lipopolysaccharide (LPS), $\mathrm{H}_{2} \mathrm{O}_{2}$, or were left "blank," indicating no serum was added to the cell culture medium.

Enzyme linked immunosorbent assay (ELISA) assays for the procollagen molecule was performed using the Metra ${ }^{\circledR}$ CICP (Quidel Corp.) assay. Collagen, a triple-helical molecule that forms the fibrous framework of all connective tissues, is synthesized as procollagen, a larger precursor molecule. Procollagen consists of mature collagen with extension peptides at both the amino and the carboxy termini. These extension peptides, or "propeptides," are cleaved from the collagen molecule by specific proteases prior to the incorporation of collagen into a growing collagen fibril. The release of these peptides into the cell culture 
media provides a stoichiometric representation of the production of collagen in a cell culture environment.

Unmodified Nafion $^{\mathrm{TM}}$ and 10\% HEMA modified Nafion ${ }^{\mathrm{TM}}$ surfaces were prepared and placed in fabricated six well plates. Surfaces were then either (a) incubated with a $10 \%$ serum (in media) solution overnight (for unmodified Nafion ${ }^{\mathrm{TM}}$ ) or (b) reacted with $200 \mu \mathrm{g} /$ $\mathrm{ml}$ YRGDS via CDI chemistry, as previously explained. ${ }^{44}$ The next day, cells were plated in two replicate wells at a density of 20000 cells/well for the unmodified Nafion ${ }^{\mathrm{TM}}$ samples or 90000 cells/well on YRGDS-modified surfaces (1\% serum solution in the medium). $24 \mathrm{~h}$ later, wells were rinsed twice with PBS, and the serum-free medium was added to make the cells quiescent. The following day, the procollagen "test" assay medium was added. Table I summarizes all substances added to cells on the different substrates and their respective concentrations. Prior to performing these experiments, the toxicity of all agents was tested at various concentrations and no change in the cell number was observed.

Once the cells were exposed to control or test medium for $24 \mathrm{~h}$, certain cell culture supernatants were collected and frozen at $-80{ }^{\circ} \mathrm{C}$ until the ELISAs were carried out. Cells still in culture wells were then quantified using either the Cell Titer 96 assay (Promega) or counted directly by staining with Live/Dead stain (Molecular Probes, Invitrogen Corp.). In this way, ELISA assays can be reported on a proprotein "per cell" basis, tracking exactly the amount of extracellular protein produced per fibroblast cell. Briefly, the medium from control wells or wells with Nafion ${ }^{\mathrm{TM}}$ samples was placed in the Metra ${ }^{\circledR}$ CICP type I collagen assay (sandwich ELISA), with the preadsorbed capture antibody for $1 \mathrm{~h}$. Plates were washed with the provided reagents and incubated with a second detection antibody. Provided reagents were added according the manufacturer's directions. ELISA plates were read on a fluorimeter plate reader $(\mathrm{Abs}=405 \mathrm{~nm})$.

\section{RESULTS AND DISCUSSION}

Cells were quantified on Nafion ${ }^{\mathrm{TM}}$ and modified Nafion ${ }^{\mathrm{TM}}$ surfaces. Adhesion assays were instrumental in determining the number of cells per $\mathrm{cm}^{2}$ that adhered to the different Nafion ${ }^{\mathrm{TM}}$ substrata, the viability/survival of the cells on the substrata, and degree of cell spreading. Figure 1 shows the average number of adherent cells per area $\left(\mathrm{cm}^{2}\right)$ on unmodified Nafion ${ }^{\mathrm{TM}}$ surfaces. Each bar graph represents the average of eight wells (as made in a custom chamber). These data are for the total adherent cells, both live and dead. Cells attached after $4 \mathrm{~h}$ to Nafion ${ }^{\mathrm{TM}}$ pretreated with either $10 \%$ serum or fibronectin were 8259 and 8730 cells $/ \mathrm{cm}^{2}$, respectively. Similar values were seen after $24 \mathrm{~h}$ of plating. This was not a surprising result, as fibronectin is rich with adhesive peptides such as RGD. Serum contains fibronectin as well as vitronectin. Bovine serum albumin, on the other hand, adhered 1602 cells $/ \mathrm{cm}^{2} 4 \mathrm{~h}$ after plating and $5248 \mathrm{cells} / \mathrm{cm}^{2}$ after a $24 \mathrm{~h}$ period. Control surfaces (TCPS) attached $\sim 5000$ cells $/ \mathrm{cm}^{2}$ after $4 \mathrm{~h}$ and $\sim 9000$ cells $/ \mathrm{cm}^{2}$ after $24 \mathrm{~h}$.

Adherent cells were examined for their viability as a function of the different proteins preexposed to the Nafion ${ }^{\mathrm{TM}}$ membranes (Table II). At either 4 or $24 \mathrm{~h}$, the viability was greatest on the Nafion ${ }^{\mathrm{TM}}$ membranes pre-exposed to fibronectin, followed by albumin and $10 \%$ serum. Untreated TCPS exhibited the lowest viability.

Figure 2 shows the typical morphology of NHDF at a 4 and $24 \mathrm{~h}$ time point. At the $4 \mathrm{~h}$ time period, we note a marked increase in cell numbers on surfaces preadsorbed with $10 \%$ serum as opposed to albumin preadsorbed surfaces. After $24 \mathrm{~h}$, we note no differences from the $4 \mathrm{~h}$ data in the morphology of cells plated on surfaces preadsorbed with albumin. Cells plated on both fibronectin exposed Nafion ${ }^{\mathrm{TM}}$ surfaces and untreated TCPS assumed a longer shape in comparison to cells on Nafion ${ }^{\mathrm{TM}}$ surfaces preadsorbed with $10 \%$ serum. The degree to which NHDF spread on was calculated using IMAGEJ. Figure 3 displays the area of cell spreading 
on Nafion ${ }^{\mathrm{TM}}$ surfaces preadsorbed with different proteins as well as untreated TCPS. Cells plated on Nafion ${ }^{\mathrm{TM}}$ preadsorbed with $10 \%$ serum had an average spread area approximately four times greater than that of cells plated on Nafion ${ }^{\mathrm{TM}}$ preadsorbed with albumin. There is a decrease in the area of cell spreading from 4 to $24 \mathrm{~h}$ on surfaces preadsorbed with fibronectin and on TCPS, as can be seen in Fig. 2.

Adhesion assays were also carried out on the modified Nafion ${ }^{\mathrm{TM}}$ surfaces. These surfaces were prepared as outlined in Ref. 44 by covalently linking the YRGDS peptide via CDI chemistry. The amount of YRGDS on these surfaces was a function of the amount of bulk fluid ( 20 or $200 \mu \mathrm{g} / \mathrm{ml}$ ) and was also dependent on the amount of hydroxyl groups that were obtained from the mixing of tetraglyme and HEMA at different ratios, as described in Ref. 44. NHDFs were then plated onto YRGDS-modified Nafion ${ }^{\mathrm{TM}}$ surfaces at $10000 / \mathrm{cm}^{2}$. Figure 4 shows the average number of cells adhering per $\mathrm{cm}^{2}$ to Nafion ${ }^{\mathrm{TM}}$ surfaces presenting increasing amounts of available hydroxyl groups and covalently decorated with YRGDS at two different surface densities. Regardless of YRGDS level used, more peptide should be coupled to the HEMA treated Nafion ${ }^{\mathrm{TM}}$ in a hydroxyl percent dependent trend. Yet, at the lower peptide concentration, NHDF cells attached in similar amounts on all HEMA treated Nafion ${ }^{\mathrm{TM}}$, except for pure HEMA modified surfaces, which showed lower adherent cell counts.

At higher concentrations, the most adherence was seen on surfaces modified with $2.5 \%$ HEMA, and a gradual increase in adhesion was observed with increasing HEMA concentrations. ANOVA was conducted in order to discern any statistical differences between surfaces adhered with $10 \%$ HEMA versus surfaces modified with $2.5 \%, 5 \%$, and pure HEMA for an adhesion period of $24 \mathrm{~h}$ and bulk peptide concentrations of 20 and 200 $\mu \mathrm{g} / \mathrm{ml}$. The $10 \%$ HEMA surfaces were chosen for this analysis as they are the subject of subsequent tests described in this article (collagen synthesis ELISA, proliferation assays, etc.). The $p$-values obtained from the analysis of the $20 \mu \mathrm{g} / \mathrm{ml}$ data indicate no statistically significant differences between $10 \%$ and $2.5 \%$ modified HEMA surface $(p=0.07)$, between $10 \%$ and 5\% HEMA $(p=0.64)$, or between 10\% HEMA and pure HEMA $(p=0.30)$. The $p$ values obtained from the analysis of the $200 \mu \mathrm{g} / \mathrm{ml}$ data also indicated no statistically significant differences between $10 \%$ and $2.5 \%$ modified HEMA surface $(p=0.12)$, between $10 \%$ and $5 \%$ HEMA $(p=0.06)$, and a between 10\% HEMA and pure HEMA $(p=0.15)$.

When comparing the values obtained between the lower and higher bulk peptide concentrations, we note that higher bulk peptide concentration does not always correlate with an increase in cell adhesion. For example, at the $200 \mu \mathrm{g} / \mathrm{ml}$ bulk peptide concentration, $5 \%$ and $10 \%$ HEMA surfaces exhibit approximately a 20\% and 13\% decrease (respectively) in cells adhered $/ \mathrm{cm}^{2}$ when comparing to adherent cells $/ \mathrm{cm}^{2}$ at the lower peptide concentration. Surfaces modified with 2.5\% HEMA and pure HEMA did not exhibit the same pattern but showed higher cell adhesion with higher bulk peptide concentration. Surfaces modified with $2.5 \%$ HEMA had a $23 \%$ increase in cell adhesion at $200 \mu \mathrm{g} / \mathrm{ml}$ bulk peptide concentration and pure HEMA had 53\% higher cell adhesion. Statistical analysis between all groups indicated no significant differences between any of the lower and higher peptide concentrations $(p=0.10)$.

To test the degree to which cells adhere to the modified surfaces on the 10\% HEMA surfaces (which were chosen for subsequent experiments), cells were plated at increasing densities. Figure 5 shows adherent live/dead cells as a function of the cell seeding concentration. At all seeding densities, the majority of cells that did attach remained viable. At all seeding densities, about $\sim 50 \%$ of cells attach. Increasing the seeding to 200000 cells/ well) only increased the number of cells attached by $65 \%$, but with a noted increase in the number of dead cells. Viability of cells plated on $10 \%$ HEMA modified Nafion ${ }^{\mathrm{TM}}$ and at the 
two different covalently bound peptide concentrations is given in Table III. From these data, we see high survival rates on all surfaces at both peptide concentrations (>88\%-98\% survival). The morphology of cells adhered to these HEMA treated-peptide presenting Nafion $^{\mathrm{TM}}$ substrata was also assessed and quantified (Fig. 6).

To better understand the degree of integrin engagement in the adhesion studies, the formation of actin cytoskeleton and the activation of paxillin in NHDF cells was measured by immunocytochemistry. As stated above, following cell adhesion experiments, surfaces were screened for optimal cell adhesion and spreading. Surfaces modified with 10\% HEMA exhibited the least amount of protein adsorption but the most cell adhesion, a goal that was set at the start of the project (i.e., a nonfouling coating, able to have bioactive properties) at the lower, $20 \mu \mathrm{g} / \mathrm{ml}$, peptide concentration. Figure 7 depicts immunocytochemistry experiments done on unmodified Nafion ${ }^{\mathrm{TM}}, 10 \%$ HEMA modified Nafion ${ }^{\mathrm{TM}}$, and a control surface (tissue culture chamber slide-TCCS). The last row, termed "merged," refers to the overlay of the two photographs. It can be discerned from these photographs that paxillin was clearly activated at the points of focal contact on all surfaces, but paxillin production was more pronounced on control surfaces. Control TCCS and unmodified Nafion ${ }^{\mathrm{TM}}$ surfaces preadsorbed with $10 \%$ serum saw the most spreading of cells, while surfaces containing the YRGDS peptide at 20 and $200 \mu \mathrm{g} / \mathrm{ml}$ concentrations spread less. A single-factor ANOVA was utilized to compare the spreading between $10 \%$ serum on unmodified surfaces versus all HEMA modified surfaces (at the $200 \mu \mathrm{g} / \mathrm{ml}$ peptide concentration). The results showed a significant decrease in spreading on HEMA modified surfaces $\left(p=3.5 \times 10^{-6}\right)$. Nevertheless, all surfaces caused the activation of paxillin protein, which indicated the binding or engagement of integrin receptors with the underlying extracellular matrix. The area of cell spreading on various modified Nafion ${ }^{\mathrm{TM}}$ surfaces was about $50 \%$ lower in comparison to unmodified Nafion ${ }^{\mathrm{TM}}$ surfaces preadsorbed with $10 \%$ serum (Fig. 3). We also note from Fig. 8 that there is an increase in cell spreading as the coupled peptide concentration increases, for all levels of HEMA treatment. This difference is statistically significant $(p=0.0007)$. So, in summary, the area of cell spreading that occurs in unmodified surfaces versus modified surfaces is significantly different. The area of cell spreading that occurs on modified surfaces is significantly higher on surface adsorbed with $200 \mu \mathrm{g} / \mathrm{ml}$ versus $20 \mu \mathrm{g} / \mathrm{ml}$ bulk peptide concentration.

Proliferation assays were performed on unmodified Nafion ${ }^{\mathrm{TM}}$ surfaces (with and without preadsorbed protein), a 10\% HEMA Nafion ${ }^{\mathrm{TM}}$ modified surface reacted with $200 \mu \mathrm{g} / \mathrm{ml}$ YRGDS peptide (as this was seen to yield the highest cell adhesion numbers), and a control TCPS surface. The results of the proliferation assay, depicted in Fig. 9, show that all cells were able to proliferate well on the unmodified Nafion ${ }^{\mathrm{TM}}$ (with $10 \%$ preadsorbed serum) and on 10\% HEMA modified Nafion ${ }^{\mathrm{TM}}$ surfaces, albeit not as efficiently as TCPS. Cells that were plated on Nafion ${ }^{\mathrm{TM}}$ without protein adhered minimally and exhibited no considerable proliferation. The Metra ${ }^{\mathrm{TM}}$ CICP procollagen peptide ELISA was used to quantify the amount of type I collagen being secreted by NHDF in response to Nafion ${ }^{\mathrm{TM}}$ on unmodified or modified surfaces and also as a result of possible biosensor chemical by-products. The assay was performed as previously outlined and data are presented below as procollagen peptides per cells (ng/cell) on the various surfaces. Figures 10 and 11 show collagen propeptide production from cells on the unmodified and modified Nafion ${ }^{\mathrm{TM}}$ surfaces, respectively (with a tenfold difference on the $y$-axis). For the most part, modified Nafion ${ }^{\mathrm{TM}}$ surfaces exhibited a tenfold decrease in the production of collagen molecules on a per cell basis. The area of cell spreading was also quantified on these surfaces. In comparison to unmodified Nafion ${ }^{\mathrm{TM}}$, there was a $40 \%$ reduction in cell spreading on $10 \%$ HEMA modified Nafion ${ }^{\mathrm{TM}}$ surfaces. These results, displayed in Fig. 12, are based on cells that were examined after 4 days of being in culture in blank serum-free media, which contained no extra additives. 
In our previous work, the degree to which Nafion ${ }^{\mathrm{TM}}$ and modified Nafion ${ }^{\mathrm{TM}}$ surfaces adsorbed proteins was analyzed as a function of the Nafion ${ }^{\mathrm{TM}}$ surface chemistry. Results indicated that the least amount of proteins adsorbed onto surfaces that were "ether carbon" rich versus surfaces displaying hydroxyl groups on the surface, which are also known to be hydrophilic. Relating surface chemistry to cell behavior, we find that the amount and type of protein that adsorbs to the surface will dictate cell behavior. Once pretreated with a protein, such as fibronectin, or a $10 \%$ serum solution (both of which are known to adhere cells), unmodified Nafion ${ }^{\mathrm{TM}}$ surfaces were able to adhere cells in a comparable fashion as the control TCPS ( 9000 cells $/ \mathrm{cm}^{2}$ for both surfaces). In addition, Nafion ${ }^{\mathrm{TM}}$ surfaces preadsorbed with protein were able to sustain the viability of NHDF, as well as provide a satisfactory substratum for cell proliferation. Tetraglyme surfaces that adhered proteins to a lower extent (protein mass/area) exhibited no cellular adhesion, as reported previously. ${ }^{105}$

Here, we observed that surfaces modified with 10\% HEMA were not only able to maintain a nonfouling substratum but also contained functional hydroxyl groups. The 10\% HEMA modified surfaces were also found to exhibit sufficient cell adhesion $\left(6167 \mathrm{cells} / \mathrm{cm}^{2}\right)$ and the highest degree of cell spreading $\left(0.002 \mathrm{~mm}^{2} /\right.$ cell at the $200 \mu \mathrm{g} / \mathrm{ml}$ bulk peptide concentration) versus other HEMA modified surfaces. For these reasons, $10 \%$ HEMA coated surfaces were examined more closely with proliferation assays, immunocytochemistry, and type I procollagen ELISAs.

The intent of the surface bound peptide sequence, YRGDS, was to attract cells to an otherwise nonfouling surface. Consequently, the number of YRGDS peptides per cell was calculated. First, the number of peptides per surface area was calculated based on the radiolabeled YRGDS. Ligands per cell were then calculated based on the area of cell spreading. Table IV tabulates the number of ligands estimated per cell. There was a tenfold increase in ligands attached to each cell as there was also a tenfold increase in the number of YRGDS molecules attached at the higher bulk protein concentration. The values obtained here are larger than the values obtained by Massia and Hubbell, in which a ligand cell density of $1.2 \times 10^{4}$ was sufficient for integrin $a v \beta 3$-mediated fibroblast spreading and that $1.2 \times 10^{5}$ was necessary for the formation of focal contacts and stress fibers. ${ }^{113}$ It should be noted that although the entire membrane was treated and the entire surface exposed to peptide, it cannot be estimated at this time whether or not complete, uniform surface coverage was reached. It was thought that the chances that a cell came in contact with a peptide on the surface were quite high. However, the affinity of the cell to the peptide was not measured as it was believed to be beyond the scope of this article. Cell affinity for the modified surfaces may be dependent on a host of parameters, namely, time and location of adhesion, interaction between cells, and cell physiology.

Modified Nafion ${ }^{\mathrm{TM}}$ surfaces displaying YRGDS peptide at different surface concentrations did not necessarily correlate with an increase in cell spreading. Figure 13 shows the relationship between cell spreading and the amount of peptide coupled to $2.5 \%, 5 \%$, and $10 \%$ HEMA and pure HEMA surfaces. The $y$ - and $x$-axes represent the average of cell spreading and the average amount of YRGDS peptide bound, respectively, and therefore no estimation of the standard error was carried out. A direct relationship is observed at lower peptide concentration, with a threshold value of approximately $0.45 \mathrm{nmol} / \mathrm{cm}^{2}(60-65 \mathrm{ng} /$ $\mathrm{cm}^{2}$ ) YRDGS molecules linked at the surface for maximum cell spreading. However, at the higher bulk peptide concentration, there is an inverse relationship between cell spreading and peptide concentration for the $2.5 \%, 5 \%$, and $10 \%$ HEMA modified surfaces. The same trend was not observed for surfaces that were coated with pure HEMA. For these modified surfaces, there appears to be an optimal concentration of bound peptide to promote maximum cell spreading, which is approximately at $0.55 \mathrm{nmoles} / \mathrm{cm}^{2}$ of YRGDS peptide. 
Many studies have been conducted to understand how cell behavior is impacted by specific ligand-integrin interactions. In particular, changes in cell shape/morphology can dictate cell function by modulating integrin signaling pathways. As outlined by Boudreau and Jones, ${ }^{114}$ the blocking of the $a v \beta 3$ integrin has been found to result in the failure of endothelial cell proliferation and survival if the cells are prevented from acquiring a spread morphology. The authors postulated that cellular rounding leads to apoptosis due to decreased integrin ligation, alluding to a change in cell signaling, as was also found by Chen et al. ${ }^{115} \mathrm{~A}$ separate study, Chen et al. correlated the formation of focal adhesions (FAs) with the degree to which a cell spreads and proposed that FA assembly scales directly with cell spreading. ${ }^{116}$ Data presented here support this work, as it showed an apparent relationship between cell spreading and the synthesis of procollagen molecules. Ivarsson et al. ${ }^{117}$ found that the production of type I collagen in cultured human foreskin fibroblasts can be regulated by cell spreading and by induction with platelet derived growth factor (PDFG-BB). Their study found that type I collagen synthesis increased markedly in proportion to cell spreading. Their findings correlate well with the results presented here using Nafion ${ }^{\mathrm{TM}}$ and modified Nafion ${ }^{\mathrm{TM}}$ substrata.

\section{CONCLUSIONS}

We found that type I collagen synthesis, known to be the main component of a fibrotic capsule, can be modulated by (as shown by a tenfold reduction) presenting cells with a (1) nonfouling substrata and (2) a bioactive peptide. This goal was accomplished via a plasma deposition method in which two monomers were combined, creating a bioactive stealth surface with tetraethylene glycol dimethyl ether (tetraglyme) and HEMA at predetermined ratios. Surfaces containing hydroxyl groups were covalently bound to a YRGDS peptide, ${ }^{44}$ and cell viability, spreading, and proliferation activation of focal contacts were quantified in addition to collagen synthesis. For the newly synthesized surfaces, there was an optimum amount of YRGDS peptide that induced an optimal degree of cell spreading, affirming that ligand density makes a difference in cell spreading, focal contact development, and subsequent cell signaling pathways, thereby altering cellular response. ${ }^{117}$ This work shows at least one potential strategy in the reduction of the fibrous capsule around implants, thereby extending implant lifetime and viability.

\section{Acknowledgments}

The authors would like to thank the NIH/NIBIB for the financial support of this work (Grant No. 1R21 EB00987) and for support of TIV through a NIH minority supplement (Grant No. 3R21 EB00987-S1). Surface modifications were carried out under the auspices of the University of Washington Engineered Biomaterials Center (Grant No. NSF EEC 9529161). XPS surface analysis was carried out through NESAC/BIO under the support from NIH/ NIBIB (Grant No. P41EB002027).

\section{References}

1. Daniloff GY. Diabetes Technol. Ther. 1999; 1:261. [PubMed: 11475272]

2. Heller A. Annu. Rev. Biomed. Eng. 1999; 1:153. [PubMed: 11701486]

3. Chung TD, Jeong RA, Kang SK, Kim HC. Biosens. Bioelectron. 2001; 16:1079. [PubMed: 11679292]

4. Yang H, Chung TD, Kim YT, Choi CA, Jun CH, Kim HC. Biosens. Bioelectron. 2002; 17:251. [PubMed: 11839479]

5. Kang SK, Jeong RA, Park S, Chung TD, Kim HC. Anal. Sci. 2003; 19:1481. [PubMed: 14640443]

6. Wang J, Musameh M. Anal. Chem. 2003; 75:2075. [PubMed: 12720343]

7. Li CM, Cha CS. Front. Biosci. 2004; 9:3479. [PubMed: 15353371]

8. Yang H, Kang SK, Choi CA, Kim H, Shin DH, Kim YS, Kim YT. Lab Chip. 2004; 4:42. [PubMed: 15007439] 
9. Hashimoto M, Sakamoto N, Upadhyay S, Fukuda J, Suzuki H. Biosens. Bioelectron. 2007; 22:3154. [PubMed: 17376670]

10. Chu M, et al. Biomed. Microdevices. 2009; 11:837. [PubMed: 19365733]

11. Cha GS, Liu D, Meyerhoff ME. Anal. Chem. 1991; 63:1666. [PubMed: 1789437]

12. Fei J, Wu Y, Ji X, Wang J, Hu S, Gao Z. Anal. Sci. 2003; 19:1259. [PubMed: 14516076]

13. Heineman WR. Appl. Biochem. Biotechnol. 1993; 41:87. [PubMed: 8215345]

14. Lin L, Xiao LL, Huang S, Zhao L, Cui JS, Wang XH, Chen X. Biosens. Bioelectron. 2006; 21:1703. [PubMed: 16203128]

15. Tohda K, Gratzl M. Anal. Sci. 2006; 22:383. [PubMed: 16733308]

16. Yang S, Atanasov P, Wilkins E. Biomed. Instrum. Technol. 1995; 29:125. [PubMed: 7773322]

17. Yu B, Moussy Y, Moussy F. Front. Biosci. 2005; 10:512. [PubMed: 15574388]

18. Ballerstadt R, Evans C, Gowda A, McNichols R. J. Diabetes Sci. Technol. 2007; 1:384. [PubMed: 19885094]

19. Barsan MM, Brett CM. Bioelectrochemistry. 2009; 76:135. [PubMed: 19349215]

20. Eisele S, Ammon HP, Kindervater R, Grobe A, Gopel W. Biosens. Bioelectron. 1994; 9:119. [PubMed: 8018313]

21. Jawaheer S, White SF, Rughooputh SD, Cullen DC. Biosens. Bioelectron. 2003; 18:1429. [PubMed: 12941557]

22. Jung SK, Gorski W, Aspinwall CA, Kauri LM, Kennedy RT. Anal. Chem. 1999; 71:3642. [PubMed: 10489519]

23. Kawanishi T, Romey MA, Zhu PC, Holody MZ, Shinkai S. J. Fluoresc. 2004; 14:499. [PubMed: 15617258]

24. Kenausis G, Chen Q, Heller A. Anal. Chem. 1997; 69:1054. [PubMed: 9075402]

25. Kim S, Rahman T, Senesac LR, Davison BH, Thundat T. Scanning. 2009; 31:204. [PubMed: 20027646]

26. Tatsumi H, Katano H, Ikeda T. Anal. Biochem. 2006; 357:257. [PubMed: 16934211]

27. Tohda K, Gratzl M. Anal. Sci. 2006; 22:937. [PubMed: 16837742]

28. Ward WK, Jansen LB, Anderson E, Reach G, Klein JC, Wilson GS. Biosens. Bioelectron. 2002; 17:181. [PubMed: 11839471]

29. Zhang Y, Hu Y, Wilson GS, Moatti-Sirat D, Poitout V, Reach G. Anal. Chem. 1994; 66:1183. [PubMed: 8160962]

30. Jung SK, Wilson GS. Anal. Chem. 1996; 68:591. [PubMed: 8999737]

31. Kerner W, Kiwit M, Linke B, Keck FS, Zier H, Pfeiffer EF. Biosens. Bioelectron. 1993; 8:473. [PubMed: 8311940]

32. Koster M, Gliesche CG, Wardenga R. Appl. Environ. Microbiol. 2006; 72:7063. [PubMed: 16936058]

33. Oh BK, Robbins ME, Nablo BJ, Schoenfisch MH. Biosens. Bioelectron. 2005; 21:749. [PubMed: 16242614]

34. Updike SJ, Shults MC, Rhodes RK, Gilligan BJ, Luebow JO, von Heimburg D. ASAIO J. 1994; 40:157. [PubMed: 8003752]

35. Wang C, Yu B, Knudsen B, Harmon J, Moussy F, Moussy Y. Biomacromolecules. 2008; 9:561. [PubMed: 18166014]

36. Ward WK, Wilgus ES, Troupe JE. Biosens. Bioelectron. 1994; 9:423. [PubMed: 7917181]

37. Yang S, Atanasov P, Wilkins E. Ann. Biomed. Eng. 1995; 23:833. [PubMed: 8572433]

38. Yang Y, Zhang SF, Kingston MA, Jones G, Wright G, Spencer SA. Biosens. Bioelectron. 2000; 15:221. [PubMed: 11219733]

39. Yu B, Ju Y, West L, Moussy Y, Moussy F. Diabetes Technol. Ther. 2007; 9:265. [PubMed: 17561797]

40. Yu B, Long N, Moussy Y, Moussy F. Biosens. Bioelectron. 2006; 21:2275. [PubMed: 16330201]

41. Ziegler M, Schlosser M, Abel P, Ziegler B. Biomaterials. 1994; 15:859. [PubMed: 7986952]

42. Florescu M, CM AB. Talanta. 2005; 65:306. [PubMed: 18969800]

Biointerphases. Author manuscript; available in PMC 2012 October 30. 
43. Moussy F, Jakeway S, Harrison DJ, Rajotte RV. Anal. Chem. 1994; 66:3882. [PubMed: 7810896] 44. Valdes TI, Ciridon W, Ratner BD, Bryers JD. Biomaterials. 2008; 29:1356. [PubMed: 18155292] 45. Zhao X, Jia H, Kim J, Wang P. Biotechnol. Bioeng. 2009; 104:1068. [PubMed: 19670265] 46. Yang L, Ren X, Tang F, Zhang L. Biosens. Bioelectron. 2009; 25:889. [PubMed: 19781932] 47. Wen D, Zou X, Liu Y, Shang L, Dong S. Talanta. 2009; 79:1233. [PubMed: 19635352] 48. Tseng TF, Yang YL, Chuang MC, Lou SL, Galik M, Flechsig GU, Wang J. Electrochem. Commun. 2009; 11:1819. [PubMed: 20161100]

49. Tan Y, Deng W, Ge B, Xie Q, Huang J, Yao S. Biosens. Bioelectron. 2009; 24:2225. [PubMed: 19153037]

50. Rakhi RB, Sethupathi K, Ramaprabhu S. J. Phys. Chem. B. 2009; 113:3190. [PubMed: 19260716]

51. Qiu B, Lin Z, Wang J, Chen Z, Chen J, Chen G. Talanta. 2009; 78:76. [PubMed: 19174206]

52. Jeykumari DR, Narayanan SS. J. Nanosci. Nanotechnol. 2009; 9:5411. [PubMed: 19928234]

53. Gopalan AI, Lee KP, Ragupathy D, Lee SH, Lee JW. Biomaterials. 2009; 30:5999. [PubMed: 19674780]

54. Endo H, Yonemori Y, Hibi K, Ren H, Hayashi T, Tsugawa W, Sode K. Biosens. Bioelectron. 2009; 24:1417. [PubMed: 18929477]

55. Chen XM, Cai ZM, Lin ZJ, Jia TT, Liu HZ, Jiang YQ, Chen X. Biosens. Bioelectron. 2009; 24:3475. [PubMed: 19482465]

56. Antonelli ML, Arduini F, Lagana A, Moscone D, Siliprandi V. Biosens. Bioelectron. 2009; 24:1382. [PubMed: 18815024]

57. Zou Y, Xiang C, Sun LX, Xu F. Biosens. Bioelectron. 2008; 23:1010. [PubMed: 18054479]

58. Zhou M, Shang L, Li B, Huang L, Dong S. Biosens. Bioelectron. 2008; 24:442. [PubMed: 18541421]

59. Yu J, Yu D, Zhao T, Zeng B. Talanta. 2008; 74:1586. [PubMed: 18371821]

60. Suganuma S, Nakajima K, Kitano M, Yamaguchi D, Kato H, Hayashi S, Hara M. J. Am. Chem. Soc. 2008; 130:12787. [PubMed: 18759399]

61. Shobha Jeykumari DR, Sriman Narayanan S. Biosens. Bioelectron. 2008; 23:1404. [PubMed: 18294834]

62. Manesh KM, Kim HT, Santhosh P, Gopalan AI, Lee KP. Biosens. Bioelectron. 2008; 23:771. [PubMed: 17905578]

63. Lu J, Do I, Drzal LT, Worden RM, Lee I. ACS Nano. 2008; 2:1825. [PubMed: 19206421]

64. Liu X, Shi L, Niu W, Li H, Xu G. Biosens. Bioelectron. 2008; 23:1887. [PubMed: 18387291]

65. Jia WZ, Hu YL, Song YY, Wang K, Xia XH. Biosens. Bioelectron. 2008; 23:892. [PubMed: 18029169]

66. Jeykumari DR, Narayanan SS. Biosens. Bioelectron. 2008; 23:1686. [PubMed: 18343650]

67. Hervás Pérez JP, López-Cabarcos E, López-Ruiz B. Talanta. 2008; 75:1151. [PubMed: 18585196]

68. Chai BH, Zheng JM, Zhao Q, Pollack GH. J. Phys. Chem. A. 2008; 112:2242. [PubMed: 18298105]

69. Zou Y, Sun LX, Xu F. Biosens. Bioelectron. 2007; 22:2669. [PubMed: 17141494]

70. Zhao ZW, Chen XJ, Tay BK, Chen JS, Han ZJ, Khor KA. Biosens. Bioelectron. 2007; 23:135. [PubMed: 17478087]

71. Zhang, N.; Wilkop, T.; Lee, S.; Cheng, Q. Analyst. Vol. 132. Cambridge, U.K.: 2007. p. 164

72. Zhang M, Mullens C, Gorski W. Anal. Chem. 2007; 79:2446. [PubMed: 17298031]

73. Yang YL, Tseng TF, Lou SL. Conf. Proc. IEEE Eng. Med. Bio. Soc. 2007; 2007:6625. [PubMed: 18003544]

74. Yan Y, Su L, Mao L. J. Nanosci. Nanotechnol. 2007; 7:1625. [PubMed: 17450935]

75. Wu L, Zhang X, Ju H. Biosens. Bioelectron. 2007; 23:479. [PubMed: 17719766]

76. Tsai YC, Chien HY. J. Nanosci. Nanotechnol. 2007; 7:1611. [PubMed: 17450933]

77. Rong LQ, Yang C, Qian QY, Xia XH. Talanta. 2007; 72:819. [PubMed: 19071692]

78. Rivas GA, Miscoria SA, Desbrieres J, Barrera GD. Talanta. 2007; 71:270. [PubMed: 19071299]

Biointerphases. Author manuscript; available in PMC 2012 October 30. 
79. Maalouf R, Chebib H, Saikali Y, Vittori O, Sigaud M, Jaffrezic-Renault N. Biosens. Bioelectron. 2007; 22:2682. [PubMed: 17161943]

80. Liu Q, Lu X, Li J, Yao X. Biosens. Bioelectron. 2007; 22:3203. [PubMed: 17416515]

81. Lee CH, Wang SC, Yuan CJ, Wen MF, Chang KS. Biosens. Bioelectron. 2007; 22:877. [PubMed: 16644200]

82. Kang X, Mai Z, Zou X, Cai P, Mo J. Anal. Biochem. 2007; 363:143. [PubMed: 17288983]

83. Cui HF, Ye JS, Zhang WD, Li CM, Luong JH, Sheu FS. Anal. Chim. Acta. 2007; 594:175. [PubMed: 17586112]

84. Chu X, Duan D, Shen G, Yu R. Talanta. 2007; 71:2040. [PubMed: 19071561]

85. Chen X, Yan X, Khor KA, Tay BK. Biosens. Bioelectron. 2007; 22:3256. [PubMed: 17314038]

86. Ahmad F, Christenson A, Bainbridge M, Yusof AP, Ab Ghani S. Biosens. Bioelectron. 2007; 22:1625. [PubMed: 16934449]

87. Zhao S, Zhang K, Bai Y, Yang W, Sun C. Bioelectrochemistry. 2006; 69:158. [PubMed: 16556513]

88. Xian Y, Hu Y, Liu F, Wang H, Jin L. Biosens. Bioelectron. 2006; 21:1996. [PubMed: 16275055]

89. Schuvailo OM, Soldatkin OO, Lefebvre A, Cespuglio R, Soldatkin AP. Anal. Chim. Acta. 2006; 573-574:110.

90. Miscoria SA, Desbrieres J, Barrera GD, Labbe P, Rivas GA. Anal. Chim. Acta. 2006; 578:137. [PubMed: 17723705]

91. Matsumoto T, Saito S, Ikeda S. J. Biotechnol. 2006; 122:267. [PubMed: 16219381]

92. Lopez MS, Mecerreyes D, Lopez-Cabarcos E, Lopez-Ruiz B. Biosens. Bioelectron. 2006; 21:2320. [PubMed: 16616485]

93. Heller A. Anal. Bioanal. Chem. 2006; 385:469. [PubMed: 16538459]

94. Diegelmann RF, Evans MC. Front. Biosci. 2004; 9:283. [PubMed: 14766366]

95. Li AG, Quinn MJ, Siddiqui Y, Wood MD, Federiuk IF, Duman HM, Ward WK. J. Biomed. Mater. Res. Part A. 2007; 82A:498.

96. Benoit DS, Anseth KS. Acta Biomater. 2005; 1:461. [PubMed: 16701827]

97. Blümmel J, Perschmann N, Aydin D, Drinjakovic J, Surrey T, Lopez-Garcia M, Kessler H, Spatz JP. Biomaterials. 2007; 28:4739. [PubMed: 17697710]

98. Chen H, Brook MA, Chen Y, Sheardown H. J. Biomater. Sci., Polym. Ed. 2005; 16:531. [PubMed: 15887658]

99. Chen H, Zhang Z, Chen Y, Brook MA, Sheardown H. Biomaterials. 2005; 26:2391. [PubMed: 15585242]

100. Porjazoska A, Yilmaz OK, Baysal K, Cvetkovska M, Sirvanci S, Ercan F, Baysal BM. J. Biomater. Sci., Polym. Ed. 2006; 17:323. [PubMed: 16689018]

101. Ratner BD, Bryant SJ. Annu. Rev. Biomed. Eng. 2004; 6:41. [PubMed: 15255762]

102. Löpez GP, Ratner BD, Tidwell CD, Haycox CL, Rapoza RJ, Horbett TA. J. Biomed. Mater. Res. 1992; 26:415. [PubMed: 1601898]

103. Johnston EE, Bryers JD, Ratner BD. Langmuir. 2005; 21:870. [PubMed: 15667162]

104. Shen M, Martinson L, Wagner MS, Castner DG, Ratner BD, Horbett TA. J. Biomater. Sci., Polym. Ed. 2002; 13:367. [PubMed: 12160299]

105. Shen M, Pan YV, Wagner MS, Hauch KD, Castner DG, Ratner BD, Horbett TA. J. Biomater. Sci., Polym. Ed. 2001; 12:961. [PubMed: 11787523]

106. Hersel U, Dahmen C, Kessler H. Biomaterials. 2003; 24:4385. [PubMed: 12922151]

107. Stevens, MP. Free Radical Polymerization Polymer Chemistry: An Introduction. Oxford University Press; New York: 1999. Chap. 6

108. Lopez GP, Ratner BD, Rapoza R, Horbett TA. Macromolecules. 1993; 26:3247.

109. Brown MC, Turner CE. Physiol. Rev. 2004; 84:1315. [PubMed: 15383653]

110. Vesey DA, Cheung C, Cuttle L, Endre Z, Gobe G, Johnson DW. J. Lab. Clin. Med. 2002; 140:342. [PubMed: 12434136] 
111. Levenson, MD.; Demetrious, AA. Metabolic Factors Wound Healing: Biochemical and Clinical Aspects. Cohoen, IK.; Diegelmann, RF.; Lindblad, WJ., editors. Saunders; Philadelphia: 1992. p. 248-273.

112. Phillips, C.; Wenstrup, R. Biosynthetic and Genetic Disorders of Collagen Wound Healing: Biochemical and Clinical Aspects. Cohoen, IK.; Diegelmann, RF.; Lindblad, WJ., editors. Saunders; Philadelphia: 1992. p. 152-176.

113. Massia SP, Hubbell JA. J. Cell Biol. 1991; 114:1089. [PubMed: 1714913]

114. Boudreau NJ, Jones PL. Biochem. J. 1999; 339:481. [PubMed: 10215583]

115. Chen CS, Mrksich M, Huang S, Whitesides GM, Ingber DE. Science. 1997; 276:1425. [PubMed: 9162012]

116. Chen CS, Alonso JL, Ostuni E, Whitesides GM, Ingber DE. Biochem. Biophys. Res. Commun. 2003; 307:355. [PubMed: 12859964]

117. Ivarsson M, McWhirter A, Borg TK, Rubin K. Matrix Biol. 1998; 16:409. [PubMed: 9524361] 


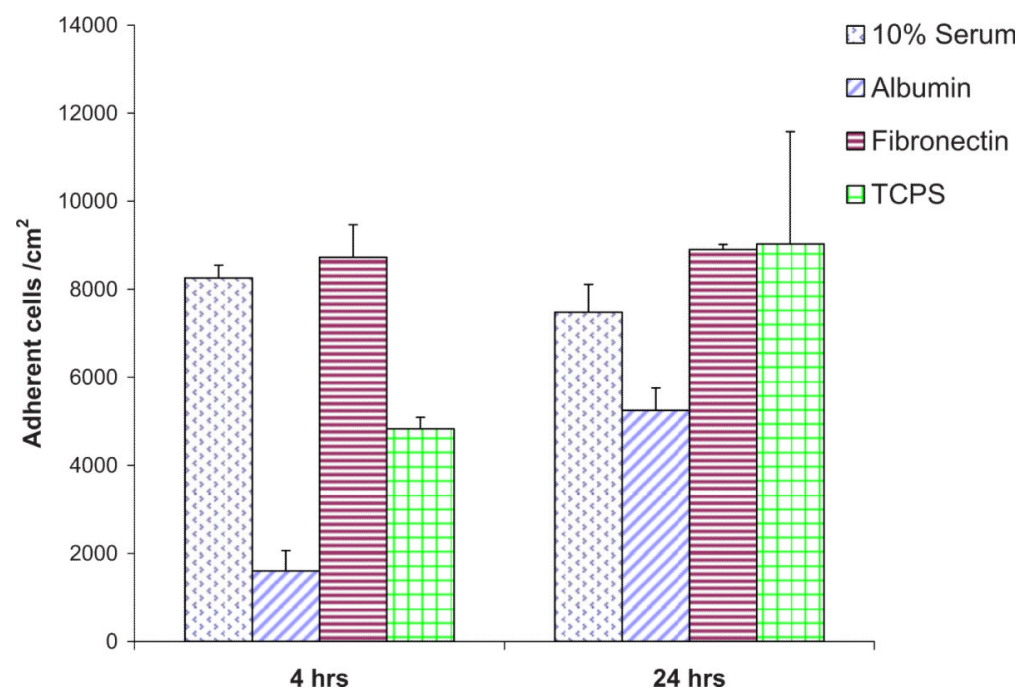

Fig. 1.

(Color online) Adherent NHDF cells $\left(\right.$ per $\mathrm{cm}^{2}$ ) on unmodified Nafion ${ }^{\mathrm{TM}}$ surfaces preadsorbed with various proteins. 


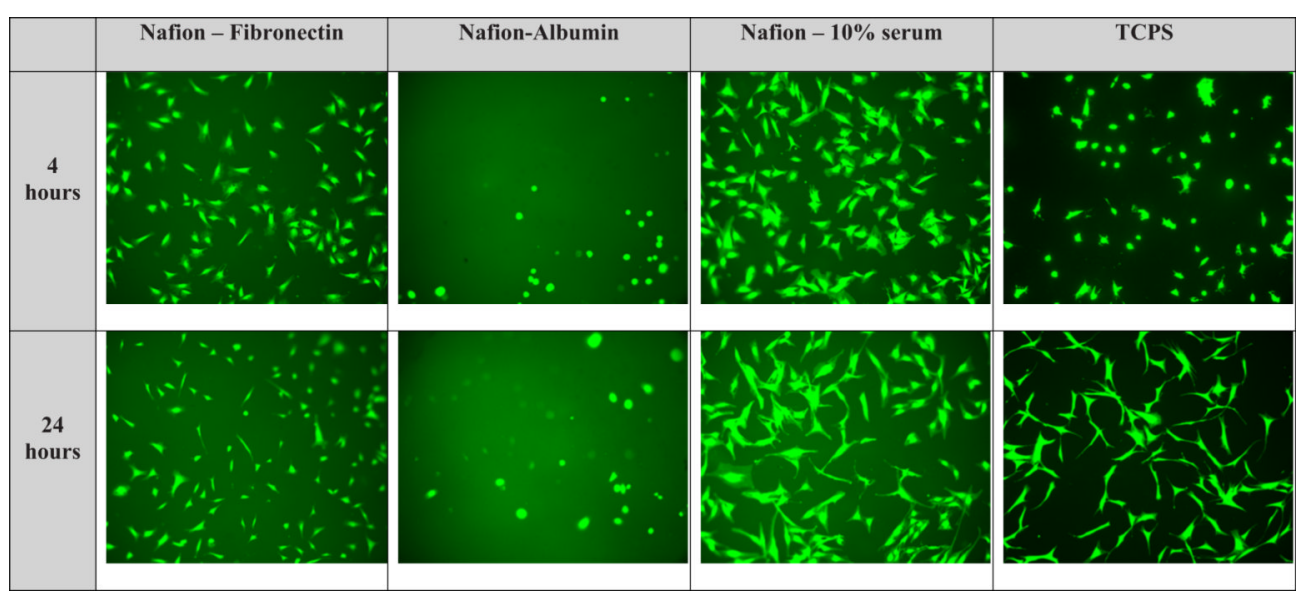

Fig. 2.

(Color online) Typical cellular morphologies for NHDF on unmodified Nafion ${ }^{\mathrm{TM}}$ surfaces and TCPS. 


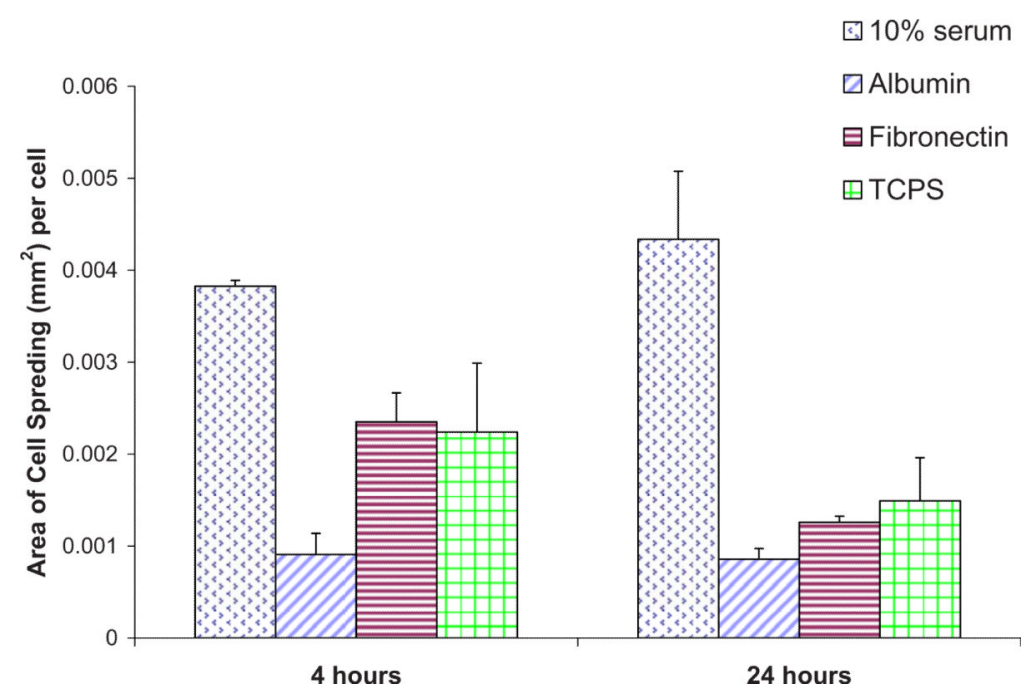

Fig. 3.

(Color online) Area of NHDF spreading quantified on unmodified Nafion ${ }^{\mathrm{TM}}$ surfaces preadsorbed with various proteins. 


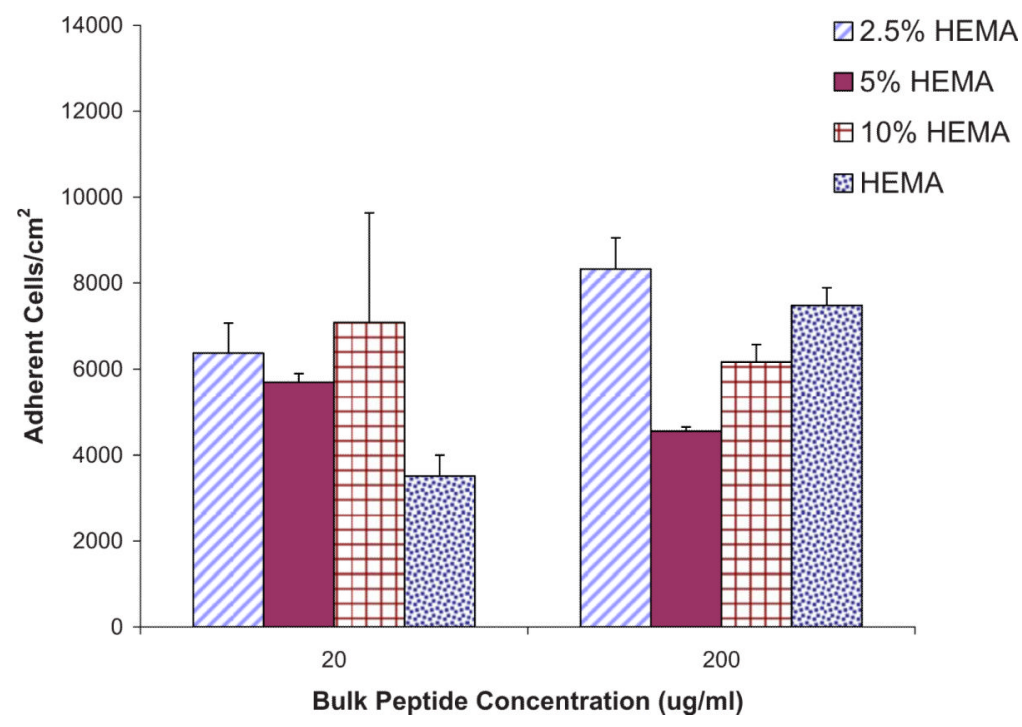

Fig. 4.

(Color online) Adherent NHDF cells $\left(\right.$ per $\mathrm{cm}^{2}$ ) on various modified Nafion ${ }^{\mathrm{TM}}$ surfaces with two different bulk peptide concentrations (actual surface concentrations unknown; only bulk concentration reported; assumes a linear relationship). 


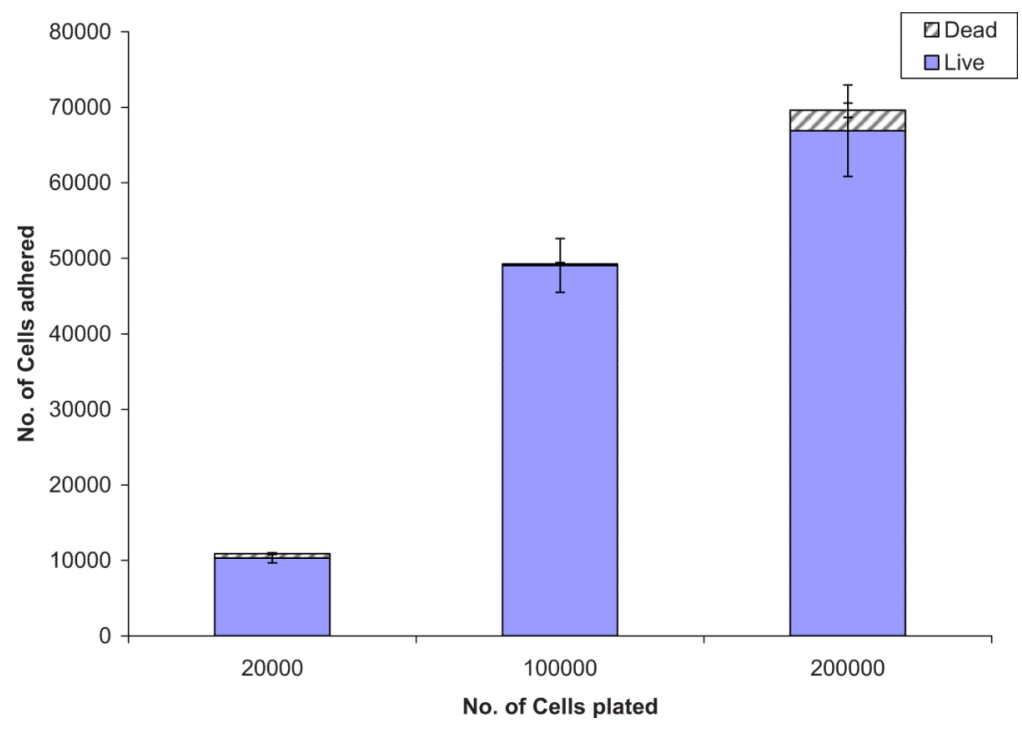

Fig. 5.

(Color online) Cells adhered on 10\% HEMA surfaces with $200 \mu \mathrm{g} / \mathrm{ml}$ YRGDS vs number of cells plated. 


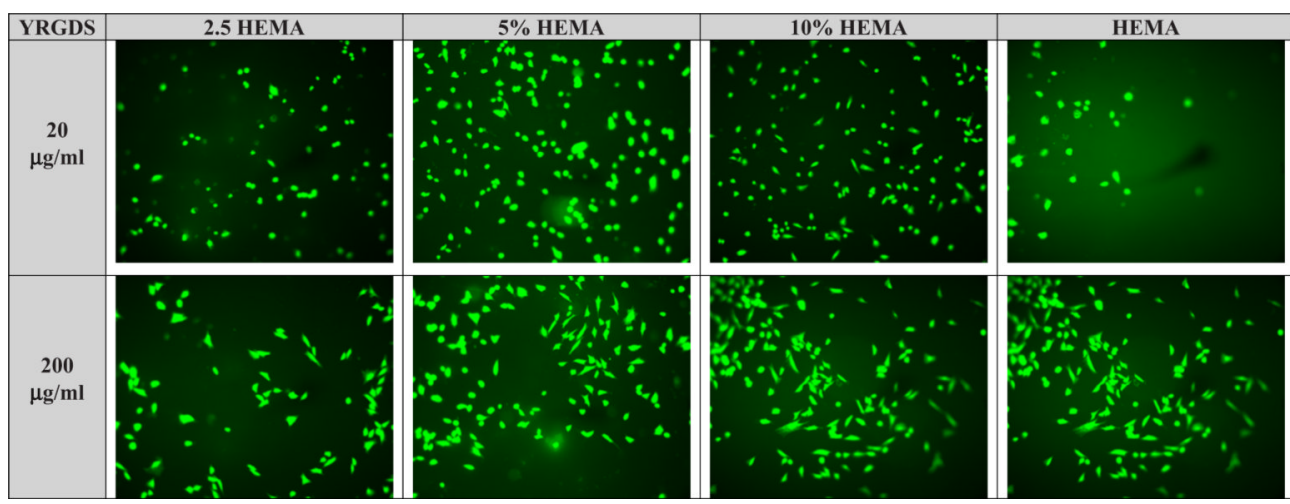

Fig. 6.

(Color online) Typical cellular morphologies for NHDF on modified Nafion ${ }^{\mathrm{TM}}$ surfaces at two different concentrations of YRGDS. Cells were allowed to adhere for $24 \mathrm{~h}$. 


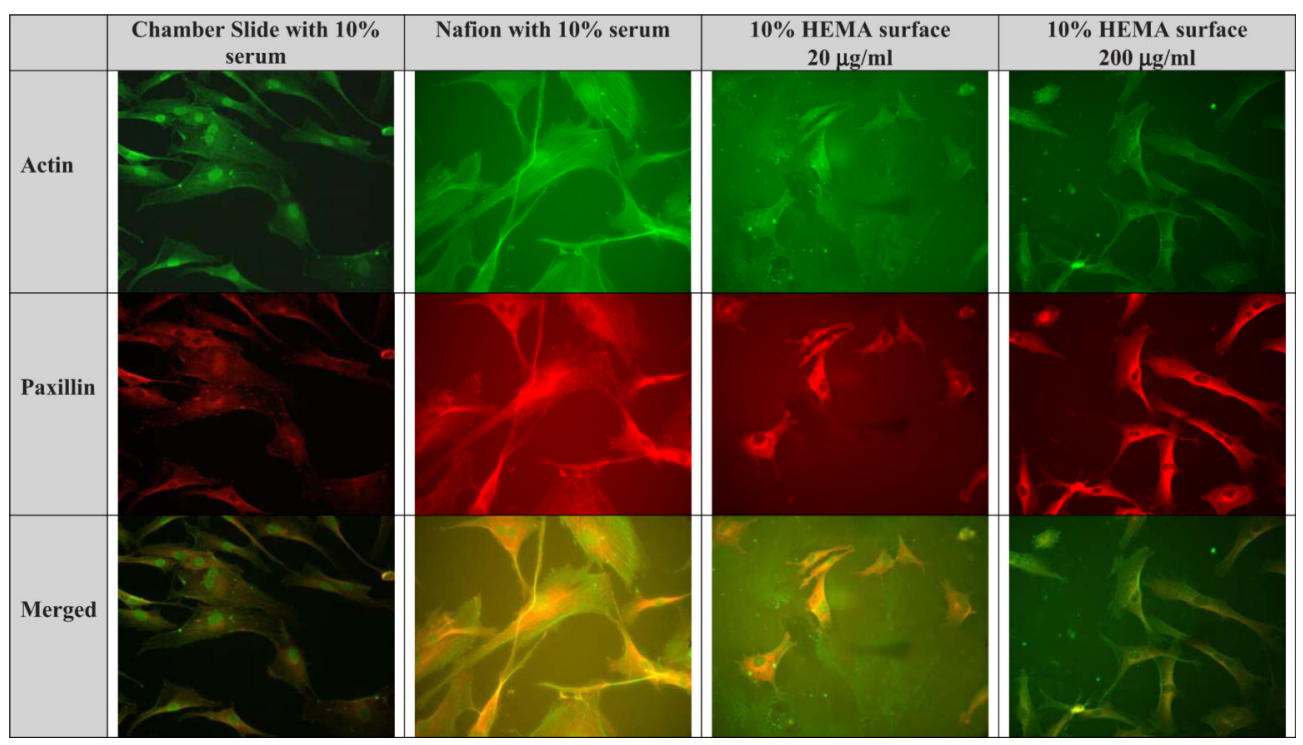

Fig. 7.

(Color online) Immunocytochemistry of NHDF on various substrata. "Merged" refers to an overlay of actin and paxillin photographs. 


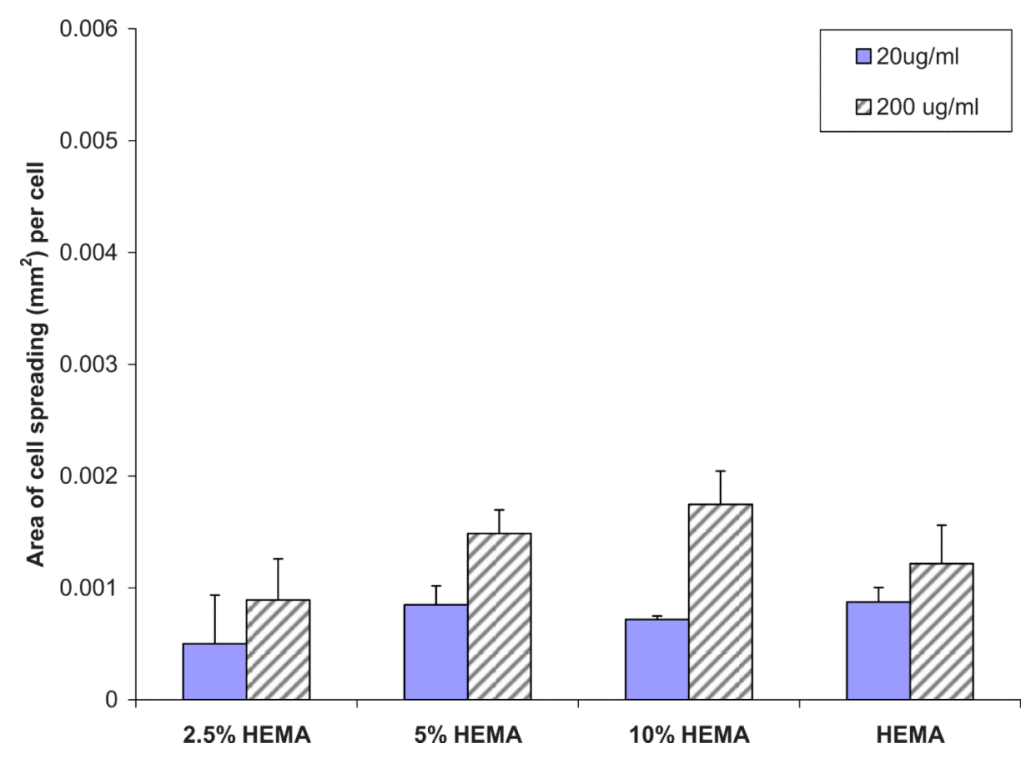

Fig. 8.

(Color online) Area of cell spreading on various modified Nafion ${ }^{\mathrm{TM}}$ surfaces. 


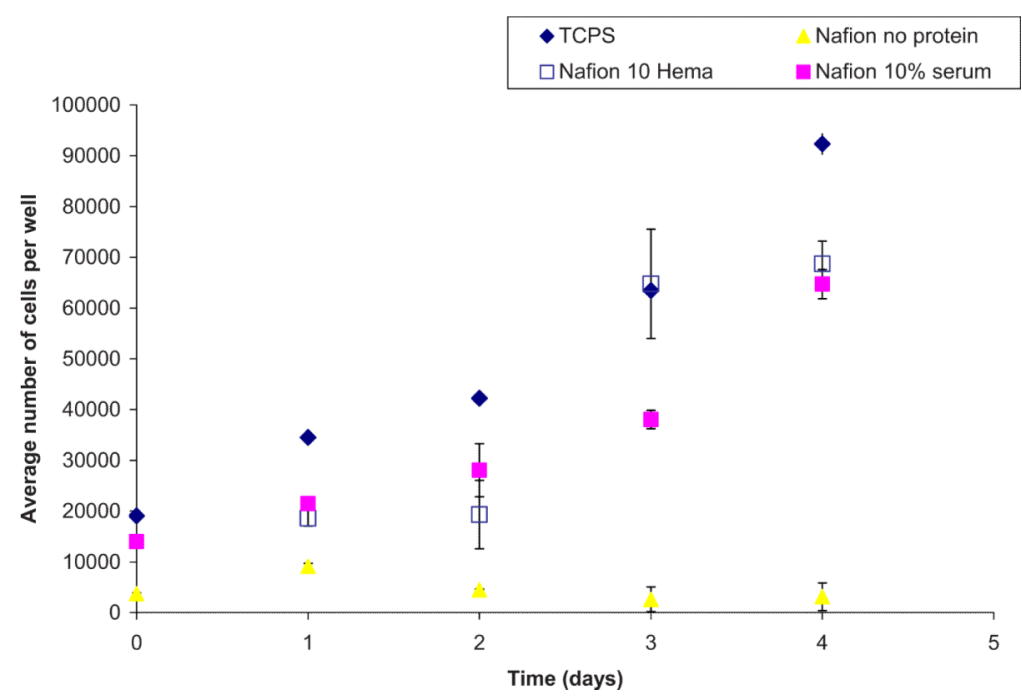

Fig. 9.

(Color online) Proliferation assay for NHDF on various Nafion ${ }^{\mathrm{TM}}$ surfaces. 


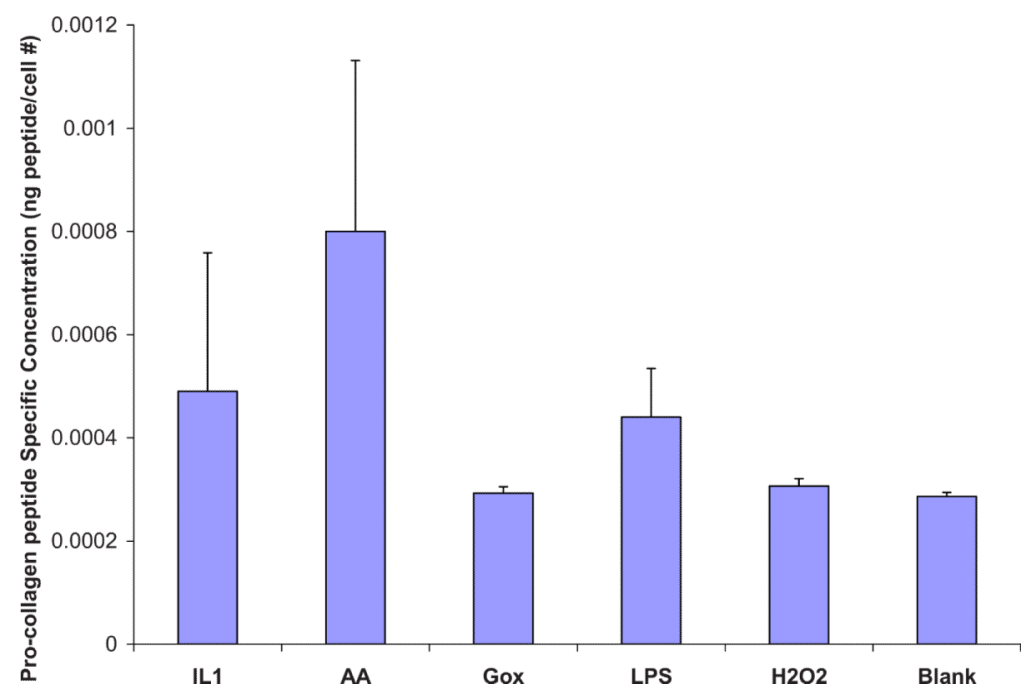

Fig. 10.

(Color online) Procollagen ELISA on unmodified Nafion ${ }^{\mathrm{TM}}$ surfaces. Results reported as procollagen peptides per cell. Blank refers to serum-free media. 


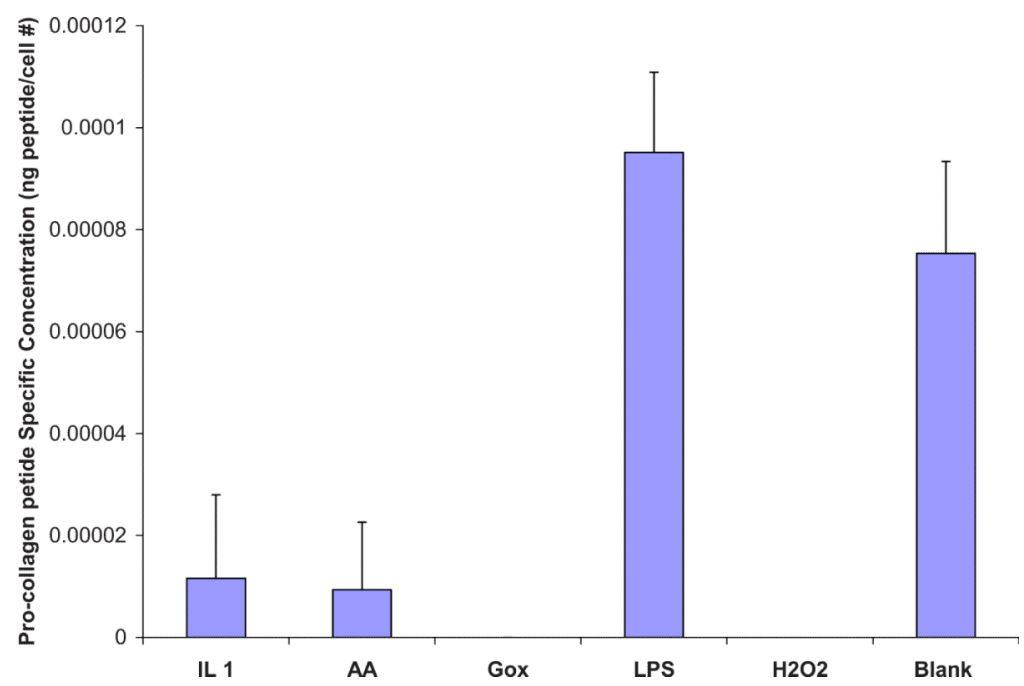

Fig. 11.

(Color online) Procollagen ELISA on 10\% HEMA modified Nafion ${ }^{\mathrm{TM}}$ surfaces. Results reported as procollagen peptides per cell. There was no detectable collagen in Gox or $\mathrm{H} 2 \mathrm{O} 2$ conditions. Blank refers to serum-free media. 


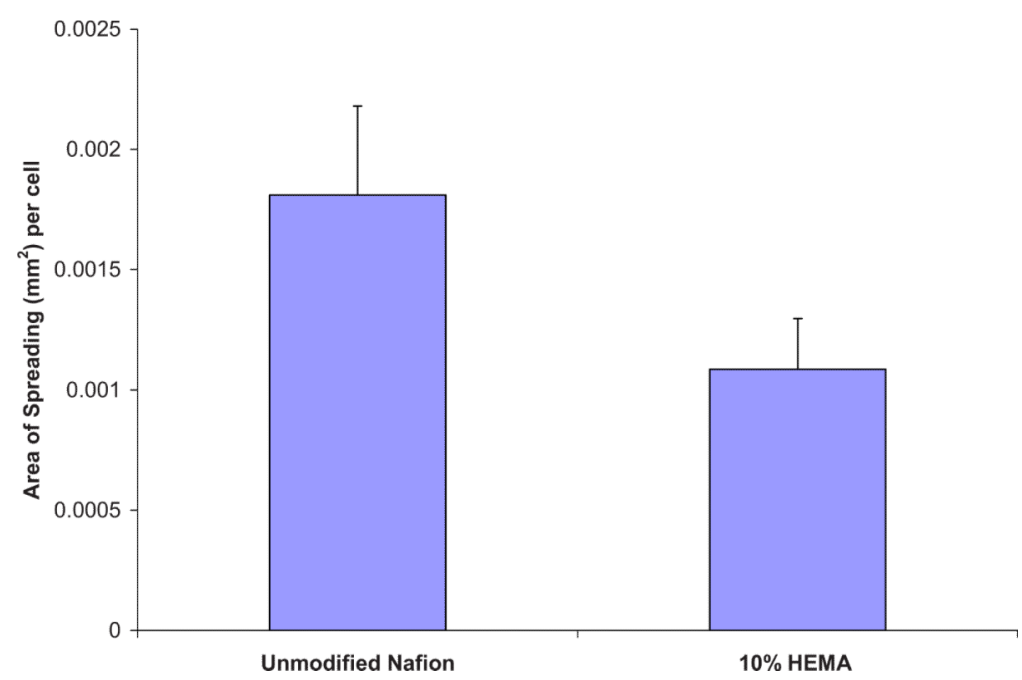

Fig. 12.

(Color online) Area of cell spreading quantified after 4 days of being in culture in blank media. 


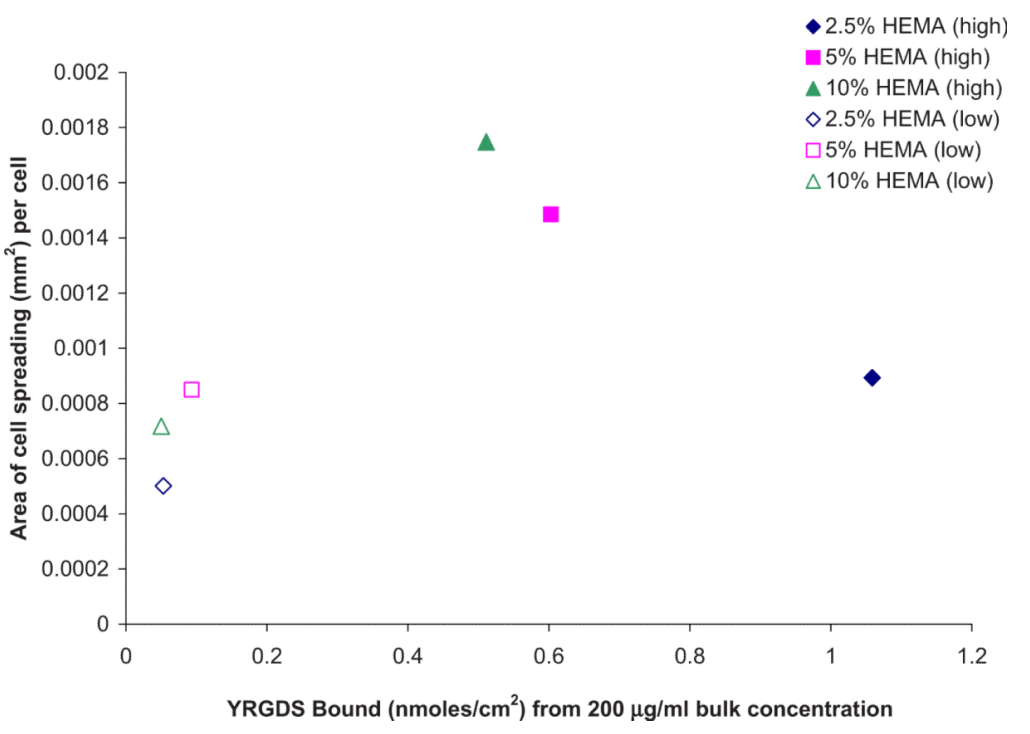

Fig. 13.

(Color online) Correlation between cell spreading and linked YRGDS at the various modified Nafion ${ }^{\mathrm{TM}}$ surfaces. 


\section{Table I}

Biosensor by-products tested in the culture media for collagen type I synthesis.

\begin{tabular}{lccc}
\hline Substance & Source & Concentration & Ref. \\
\hline Ascorbic acid & Sigma A4544 & $50 \mu \mathrm{g} / \mathrm{ml}$ & 11 \\
$\mathrm{H}_{2} \mathrm{O}_{2}$ & Sigma H1009 & $20 \mu \mathrm{M}$ & Experimental, 12 \\
Gox & Fluka 49182 & $0.2 \mathrm{mU} / \mathrm{ml}$ & 13 \\
LPS & Sigma 4391 & $3 \mu \mathrm{g} / \mathrm{ml}$ & 14 \\
IL-1 & Sigma I-9401 & $1 \mathrm{ng} / \mathrm{ml}$ & 8 \\
\hline
\end{tabular}




\section{Table II}

Viability of cells adhered to unmodified Nafion ${ }^{\mathrm{TM}}$ surfaces via different proteins.

\begin{tabular}{lccccc}
\hline & \multicolumn{2}{c}{$\mathbf{4 h}$} & & \multicolumn{2}{c}{$\mathbf{2 4} \mathbf{~ h}$} \\
\cline { 2 - 3 } \cline { 5 - 6 } Protein & \% Live & \% Dead & & \% Live & \% Dead \\
\hline Fibronectin & $96.8 \pm 0.63$ & $1.37 \pm 0.64$ & & $99.37 \pm 0.12$ & $0.63 \pm 0.12$ \\
Albumin & $96.3 \pm 2.4$ & $3.72 \pm 2.40$ & & $77.31 \pm 4.61$ & $12.02 \pm 4.41$ \\
10\% serum & $96.8 \pm 0.47$ & $3.25 \pm 0.47$ & & $92.95 \pm 3.37$ & $5.83 \pm 3.97$ \\
TCPS (no protein) & $89.47 \pm 3.18$ & $10.53 \pm 3.17$ & & $85.78 \pm 1.80$ & $14.22 \pm 1.80$ \\
\hline
\end{tabular}




\section{Table III}

Viability of cells ( \pm standard error of the mean) adhered to various HEMA modified Nafion ${ }^{\mathrm{TM}}$ surfaces via YRGDS peptide at two different concentration (BC: bulk concentration).

\begin{tabular}{lccccc}
\hline & \multicolumn{2}{c}{ YRGDS $(\mathbf{B C}=\mathbf{2 0} \boldsymbol{\mu} \mathbf{g} / \mathbf{m l})$} & & \multicolumn{2}{l}{ YRGDS $(\mathbf{B C}=\mathbf{2 0 0} \boldsymbol{\mu g} / \mathbf{m l})$} \\
\cline { 2 - 3 } Surface & \% Live & \% Dead & & \% Live & \% Dead \\
\hline $2.5 \%$ HEMA & $95.24 \pm 3.2$ & $4.76 \pm 3.2$ & & $90.1 \pm 6.37$ & $8.19 \pm 6.37$ \\
$5 \%$ HEMA & $98.34 \pm 1.6$ & $1.65 \pm 1.6$ & $93.85 \pm 5.8$ & $6.14 \pm 5.18$ \\
$10 \%$ HEMA & $97.09 \pm 0.56$ & $2.91 \pm 0.56$ & $94.45 \pm 0.59$ & $5.55 \pm 0.59$ \\
HEMA & $88.78 \pm 1.14$ & $11.21 \pm 0.57$ & & $97.43 \pm 1.43$ & $2.5 \pm 1.43$ \\
\hline
\end{tabular}




\section{Table IV}

Calculated YRGDS molecules per cell for each of the modified surfaces (details provided in text).

\begin{tabular}{|c|c|c|c|}
\hline Bulk YRGDS-20 $\mu \mathrm{g} / \mathrm{ml}$ & mole $/ \mu \mathbf{m}^{2}$ & Area of cell $\left(\mu \mathrm{m}^{2} /\right.$ cell $)$ & Ligands/cell \\
\hline $2.5 \%$ HEMA & $3.21 \times 10^{5}$ & $5.02 \times 10^{2}$ & $1.61 \times 10^{8}$ \\
\hline $5 \%$ HEMA & $5.63 \times 10^{5}$ & $8.50 \times 10^{2}$ & $4.79 \times 10^{8}$ \\
\hline $10 \%$ HEMA & $3.02 \times 10^{5}$ & $7.18 \times 10^{2}$ & $2.17 \times 10^{8}$ \\
\hline HEMA & $2.09 \times 10^{6}$ & $8.75 \times 10^{2}$ & $1.83 \times 10^{9}$ \\
\hline Bulk YRGDS-200 $\mu \mathrm{g} / \mathrm{ml}$ & mole / $\mu \mathbf{m}^{2}$ & Area of cell $\left(\mu \mathbf{m}^{2} /\right.$ cell $)$ & Ligands/cell \\
\hline $2.5 \%$ HEMA & $6.38 \times 10^{6}$ & $8.93 \times 10^{2}$ & $5.69 \times 10^{9}$ \\
\hline $5 \%$ HEMA & $3.63 \times 10^{6}$ & $1.49 \times 10^{3}$ & $5.39 \times 10^{9}$ \\
\hline $10 \%$ HEMA & $3.08 \times 10^{6}$ & $1.75 \times 10^{3}$ & $5.38 \times 10^{9}$ \\
\hline HEMA & $8.21 \times 10^{6}$ & $1.22 \times 10^{3}$ & $9.99 \times 10^{9}$ \\
\hline
\end{tabular}

